\title{
PENGARUH PEMENUHAN KEBUTUHAN REMAJA TERHADAP PERILAKU AGRESIF SISWA DI PKBM KASIH BUNDO KOTA BUKITTINGGI
}

\section{Fadhilla Yusri}

Jurusan BK Fakultas Tarbiyah dan Ilmu Keguruan LAIN Bukittinggi

e-mail:fadhillayusri@gmail.com

\section{Jasmienti}

Fakultas Tarbiyah dan Ilmu Keguruan IAIN Bukittinggi

e-mail:jasmienti@gmail.com

DOI: http:/ / dx.doi.org/10.30983/islam_realitas.v3i1.214

Diterima: 14 Juni 2017
Diterbitkan: 8 Agustus 2017

\begin{abstract}
One things that need to be fulfilled in adolescence development is their needs. Adolescents as everyone else use all their time to try to satisfy their physical, social, emotional, and other personal needs. If each of their needs can not be minimally fulfilled, then the adolescents will face the slowness in achieving their developmental tasks and even show deviant behavior. Adolescents whose needs are not fulfilled can perform a self-defensive bebaviors such as aggressive behavior, compensation, identification, rationalization, egocentricity, withdrawal as well as impaired physical growth. One of the effects of the unfulfillness of adolescents' needs is aggressive behavior. Individual aggressive behavior will have a very detrimental effect, both for the individual itself and for others. This study was conducted to determine the effect of Adolescentss' needs on aggressive bebavior of students in PKBM Kasib Bundo Kota Bukittinggi. Based on the results of the research, the fulfillment of the needs of adolescents associated with aggressive behavior they did in life; adolescent satisfaction affected $6.35 \%$ of aggressive behavior of adolescent, while the other $93.65 \%$ was influenced by various other factors.
\end{abstract}

Keywords: Adolescent Needs and Aggressive Behavior.

\section{Abstrak}

Salah satu hal yang perlu dipenuhi dalam masa perkembangan remaja adalah kebutuhan remaja. Remaja sebagaimana setiap orang lainnya mempergunakan seluruh waktunya untuk mencoba memuaskan kebutuhan fisik, sosial, emosional dan kebutuhan pribadinya yang lain. Jika masing-masing kebutuhan remaja tidak dapat terpenuhi secara minimal, maka remaja akan mengalami kelambatan dalam pencapaian tugas perkembangan mereka dan bahkan memperlihatkan tingkah laku yang menyimpang. Remaja yang kebutuhannya tidak terpenuhi dapat melakukan tingkah laku mempertahankan diri seperti tingkah laku agresif, kompensasi, identifikasi, rasionalisasi, egosentrism, menarik diri serta gangguan pertumbuhan fisik. Salah satu dampak dari tidak terpenuhinya kebutuhan remaja adalah perilaku agresif. Perilaku agresif individu akan menimbulkan dampak yang sangat merugikan, baik bagi individu itu sendiri maupun bagi orang lain. Penelitian ini dilakukan untuk mengetahui pengaruh pemenuhan kebutuhan remaja terhadap perilaku agresif siswa di PKBM Kasih Bundo Kota Bukittinggi. Berdasarkan hasil penelitian diketahui bahwa pemenuhan kebutuhan remaja berhubungan dengan perilaku agresif yang dilakukannya dalam kehidupan. Di mana pemenuhan kebutuhan remaja mempengaruhi 6,35\% perilaku agresif pada diri remaja. Sedangkan 93,65\% lainnya dipengaruhi oleh berbagai faktor yang lainnya.

Kata Kunci: Kebutuhan Remaja dan Perilaku Agresif.

\section{Latar Belakang}

Penulis tertarik untuk melakukan penelitian tentang pengaruh pemenuhan kebutuhan remaja terhadap perilaku agresif siswa di PKBM Kasih
Bundo Kota Bukittinggi. Rumusan masalah yang diajukan dalam penelitian ini adalah adakah pengaruh pemenuhan kebutuhan remaja terhadap perilaku agresif siswa di PKBM Kasih 
Bundo Kota Bukittinggi? Sedangkan tujuan penelitian ini adalah untuk mengetahui pengaruh pemenuhan kebutuhan remaja terhadap perilaku agresif siswa di PKBM Kasih Bundo Kota Bukittinggi.

Setiap satuan pendidikan, baik formal, nonformal maupun informal memberikan pelayanan pendidikan bagi peserta didiknya. Pada umumnya peserta didik yang mendapatkan pelayanan pada satuan pendidikan dasar dan menengah berada pada rentang perkembangan remaja. Usia remaja merupakan usia yang sangat urgen dalam rentang perkembangan hidup manusia. Dari segi umur, para pakar psikologi sepakat bahwa yang dimaksud dengan remaja adalah seorang individu yang berada pada rentang usia antara 13 sampai dengan 21 tahun'. Pada masa remajalah setiap individu mengalami perubahan fisik paling pesat, mempunyai energi yang berlimpah, berada pada periode yang idealis, menunjukkan kemandirian serta berada dalam proses pencarian jati dirinya. Pada masa remaja ini individu mengalami banyak tantangan dari dalam dirinya, maupun tantangan dari lingkungan luar diri terutama lingkungan sosial. Oleh karena itu orang-orang yang bekerja dengan remaja perlu memahami hakikat perkembangan remaja dengan sungguh-sungguh, supaya dapat membantu mereka dengan tepat menghadapi perkembangan mereka.

Usia remaja merupakan usia yang sangat urgen dalam rentang perkembangan hidup manusia. Salah satu hal yang perlu dipenuhi dalam masa perkembangan remaja adalah kebutuhan remaja. Kebutuhan remaja adalah segala sesuatu yang muncul secara naluriah dan sangat diperlukan oleh remaja untuk dapat menjalankan masa perkembangan remajanya dan memenuhi tugas perkembangannya. ${ }^{2}$ Kebutuhan remaja

\footnotetext{
${ }^{1}$ Elida Prayitno dan Erlamsyah, Psikologi Perkembangan Remaja (Padang: UNP Press, 2002), h. 5.

${ }^{2}$ F. J. Monks; A.M.P. Knoers; Siti Rahayu Haditono, Psikologi Perkembangan (Yogyakarta: UGM PRESS, 2006), h. 275.
}

dapat dipuaskan dengan berbagai cara misalnya kebutuhan sosial dapat dipuaskan melalui penerimaan sosial dan dapat juga dengan menghadapkan mereka pada berbagai tantangan sosial atau kesulitan sosial.

Senada dengan itu, Elida Prayitno menyatakan bahwa kebutuhan remaja adalah salah satu aspek fisik dan psikologis yang menggerakkan remaja dalam aktivitas-aktivitasnya dan menjadi dasar (alasan) bagi setiap remaja untuk berusaha ${ }^{3}$. Kebutuhan tidak terlepas dari kehidupan sehari-hari. Selama hidup manusia membutuhkan bermacam-macam kebutuhan. Seperti: makanan, pakaian, perumahan, pendidikan, keamanan dan kesehatan. Kebutuhan dipengaruhi oleh kebudayaan, lingkungan, waktu, dan agama. Semakin tinggi tingkat kebudayaan suatu masyarakat, semakin tinggi dan banyak pula macam kebutuhan yang harus dipenuhi.

Dengan penguasaan dan pemenuhan kebutuhan itu, remaja dapat hidup layak sesuai dengan tuntutan lingkungan mereka. Di samping rumusan tersebut, ada tujuh jenis kebutuhan khas remaja yang dikemukakan oleh Garrison dalam Andi Mappiare, yaitu 1). Kebutuhan untuk memperoleh kasih sayang, 2). Kebutuhan untuk diikutsertakan dan diterima oleh kelompoknya, 3) Kebutuhan untuk mampu mandiri, 4) Kebutuhan untuk mampu berprestasi, 5) Kebutuhan untuk memperoleh pengakuan dari orang lain, 6) Kebutuhan untuk dihargai, 7) Kebutuhan untuk mendapatkan filsafat hidup ${ }^{4}$.

Untuk memungkinkan tercapainya tugastugas perkembangan pada periode remaja, maka ada beberapa kebutuhan perkembangan remaja yang harus dipenuhi. Elida Prayitno mengklasifikasikan kebutuhan remaja, sebagai berikut ${ }^{5}$ :

Pertama, kebutuhan fisik. Kebutuhan fisik remaja yang harus dipenuhi adalah kebutuhan makan, minum, udara segar, temperatur yang

${ }^{3}$ Elida Prayitno, Psikologi Perkembangan Remaja, h. 25.

${ }^{4}$ Andi Mappiare, Psikologi Remaja (Surabaya: Usaha Nasional, 1982), h. 41.

${ }^{5}$ Elida Prayitno, Psikologi Perkembangan Remaja, h. 26. 
sesuai, beristirahat, dan beraktivitas. Sebagai manusia pada umumnya remaja memiliki kebutuhan fisik yang sama dengan manusia pada umumnya.

Kedua, kebutuhan psikologis. Kebutuhan psikologis yang paling menonjol pada periode remaja adalah: a) Kebutuhan untuk mendapatkan status. Remaja butuh merasa berguna, penting, atau memiliki kebanggaan terhadap dirinya sendiri. Remaja butuh kebanggaan untuk diterima dan dikenal sebagai individu yang berarti dalam kelompok teman sebayanya. Penerimaan dan dibanggakan kelompok sangat penting bagi remaja dalam mencari kepercayaan diri dan kemandiriannya. b) Kebutuhan mandiri. Remaja ingin lepas dari batasan atau aturan orang tua dan mencoba mengarahkan atau mendisiplinkan dirinya sendiri. Remaja ingin mengatur kehidupan sosial, keuangan dan kehidupan pribadinya. Remaja ingin bebas dari tingkah laku orang tua yang terlalu mencampuri urusannya, walaupun mereka sangat senang jika orang tua memperhatikan kesedihan dan kebahagiaan mereka. c) Kebutuhan berprestasi. Untuk dapat memenuhi kebutuhan berprestasi remaja, maka dalam penilaian belajar guru diharapkan dapat lebih menekankan kepada usaha siswa bukan semata-mata menilai hasil, tanpa memperhatikan proses yang dilakukan siswa. Siswa harus diberi penghargaan untuk waktu yang mereka habiskan guna melakukan kegiatan sekolah. d) Kebutuhan diakrabi. Remaja butuh untuk dipahami ide, kebutuhan dan permasalahan yang dihadapinya. Remaja butuh didengarkan oleh orang tua, guru dan teman sebayanya segala hal yang menyangkut ide, kebutuhan dan permasalahannya. Jika hal itu terjadi, maka remaja merasa tersokong, dihargai dan bahagia. e) Kebutuhan memiliki filsafat hidup. Remaja mulai tertarik untuk mengetahui tentang kebenaran, keagamaan dan nilai-nilai ideal. Suatu filsafat hidup yang memuaskan adalah yang bernilai kemanusiaan. Jika filsafai hidup ini dimiliki oleh remaja, maka akan menimbulkan perasaan aman dan damai dalam diri remaja itu.
Urgensi dari setiap kebutuhan tersebut antara individu yang satu dengan yang lainnya tidak sama persis, karena dipengaruhi oleh faktor individu, faktor sosial, faktor kultural, dan faktor religius (termasuk nilai-nilai yang dianut). Masingmasing faktor tersebut dapat mewarnai tinggi rendahnya tingkat pengharapan atas pemenuhan setiap kebutuhan tersebut.

Pada dasarnya setiap remaja menghendaki semua kebutuhannya dapat terpenuhi secara wajar. Terpenuhinya kebutuhan-kebutuhan tersebut secara memadai akan menimbulkan keseimbangan dan keutuhan pribadi. Remaja yang kebutuhannya terpenuhi secara memadai akan memperoleh kepuasan hidup. Selanjutnya remaja akan merasa gembira, harmonis, dan produkif manakala kebutuhannya dapat terpenuhi secara memadai.

Usaha untuk memenuhi kebutuhan mendapatkan status dapat dilakukan dengan mengembangkan bakat khusus dengan memberikan berbagai rangsangan dan menghargai prestasi dalam bakat khusus itu'. Penghargaan prestasi dalam bakat khusus sama nilainya dengan prestasi dalam bidang akademik. Berikan penghargaan kepada siswa sesuai dengan kecepatan dan prestasi mereka masing-masing.

Untuk memenuhi kebutuhan mandiri remaja, maka berikan kesempatan kepada remaja membuat program untuk pengembangan bakat mereka ${ }^{7}$. Selain itu dapat juga memberikan kesempatan untuk mengemukakan ide-ide dalam mengambil keputusan memilih kelompok, jurusan dan program pengembangan bakat. Memberikan penghargaan kepada kelompok siswa yang menampakkan kreativitas, mencari sumbersumber belajar sendiri.

Kebutuhan berprestasi dapat dipenuhi dengan memberikan penilaian, kalau siswa telah menguasai apa yang dipelajarinya, sehingga siswa mendapatkan nilai baik $^{8}$. Menjauhkan

${ }^{6}$ Elida Prayitno, Psikologi Perkembangan Remaja, h. 31. ${ }^{7}$ Elida Prayitno, Psikologi Perkembangan Remaja, h. 31. ${ }^{8}$ Elida Prayitno, Psikologi Perkembangan Remaja, h. 32. 
memberikan penilaian kalau siswa belum menguasai materi pelajaran yang mengakibatkan nilai siswa rendah. Memotivasi dengan cara membandingkan prestasi siswa dengan prestasinya sendiri sebelumnya yang mendorong dia untuk memahami dirinya sebagai siswa yang mampu berprestasi. Selain itu membantu siswa mengembangkan bakat-bakat khusus secara serius, sehingga prestasi bakat khusus dapat dibanggakan dalam kelompok juga dapat dilakukan.

Kebutuhan untuk diakrabi dapat dipenuhi dengan guru membina kedekatan psikologis dengan siswanya, guru berusaha menyayangi siswa dengan cara membantu mereka mengatasi kesulitan dalam belajar maupun kesulitan pribadi? Selalu bekerja sama dalam berbagai kesempatan, misalnya menyusun program kebersihan, program pengembangan bakat dan program kegiatan rekreasi.

Untuk memenuhi kebutuhan filsafat hidup dapat dilakukan dengan memberikan informasi tentang nilai kebenaran dalam kehidupan melalui berbagai mata pelajaran yang terkait ${ }^{10}$. Menjadikan guru dan teman sebaya sebagai model yang menerapkan nilai kebenaran, agama dan ilmu penngetahuan dalam kehidupan. Melakukan bimbingan dan konseling kelompok atau individual untuk membentuk keyakinan dan keterampilan memecahkan masalah kehidupan dengan cara-cara yang bernilai.

Usaha memenuhi kebutuhan bagi remaja tidaklah mudah, melainkan sangat rumit, kompleks dan bervariasi. Sebagai contoh kebutuhan remaja yang sering kurang terpenuhi adalah kebutuhan akan kasih sayang dari orang tua maupun orang dewasa lainnya. Hal ini akan mengakibatkan remaja cenderung mencari penyelesaiannya sendiri dengan cara membenci orang tua, suka mencari perhatian orang lain, lebih betah berkumpul dengan teman sebayanya, mencari orang lain sebagai pengganti orang

${ }^{9}$ Elida Prayitno, Psikologi Perkembangan Remaja, h. 32.

${ }^{10}$ Elida Prayitno, Psikologi Perkembangan Remaja, h. 32. tuanya, yang dapat memenuhi kebutuhannya itu seperti gurunya, pemuka masyarakat, mencintai orang yang lebih dewasa dan sebagainya.

Hardy and Gull dalam Elida Prayitno berpendapat bahwa apabila kebutuhan remaja itu terintangi atau tidak terpuaskan akan timbul perasaan kecewa atau frutrasi ${ }^{11}$. Apabila kebutuhan sosial-psikologis tidak terpenuhi maka akan mengakibatkan timbulnya rasa tidak puas, menjadi frustasi dan terhambatnya pertumbuhan serta perkembangan sikap positif terhadap lingkungan dan dirinya. Sebagai contoh masa remaja disebut pula sebagai masa social bunger (kehausan sosial), yang ditandai dengan adanya keinginan untuk bergaul dan diterima di lingkungan kelompok sebayanya (per kelompok). Penolakan dari kelompok dapat menimbulkan frustrasi dan menjadikan dia sebagai isolated dan merasa rendah diri.

Blair and Stewart dalam Elida Prayitno menyatakan bahwa siswa remaja yang kebutuhannya tidak terpenuhi dapat melakukan tingkah laku mempertahankan diri seperti tingkah laku agresif, kompensasi, identifikasi, rasionalisasi, proyeksi, pembentukan reaksi, egosentrisme, menarik diri serta gangguan pertumbuhan fisik ${ }^{12}$. Jika masing-masing kebutuhan remaja tidak dapat terpenuhi secara minimal, maka remaja akan mengalami kelambatan dalam pencapaian tugastugas perkembangan mereka dan bahkan memperlihatkan tingkah laku yang menyimpang.

Salah satu dampak dari tidak terpenuhinya kebutuhan remaja adalah perilaku agresif. Menurut Myers dalam Sarwono mengatakan bahwa perilaku agresif adalah kebutuhan untuk menyerang, memperkosa atau melukai orang lain, untuk meremehkan, merugikan, mengganggu, membahayakan, merusak, menjahati, mengejek, mencemoohkan, atau menuduh secara jahat, menghukum berat, atau melakukan tindakan

\footnotetext{
${ }^{11}$ Elida Prayitno, Psikologi Perkembangan Remaja, h. 32.

${ }^{12}$ Elida Prayitno dan Erlamsyah, Psikologi Perkembangan Remaja, h. 33.
} 
sadistis lainnya. ${ }^{13}$ Perilaku agesif bukan suatu perilaku yang dengan sendirinya ada di dalam diri manusia. Perilaku agresif individu akan menimbulkan dampak yang sangat merugikan, baik bagi individu itu sendiri maupun bagi orang lain.

Dayakisni dan Hudaniah mengartikan agresi sebagai suatu serangan yang dilakukan oleh suatu organism terhadap organism lain, objek lain dan bahkan dirinya sendiri ${ }^{14}$. Pengrusakan barang dan perilaku destruktif lainnya juga termasuk dalam definisi agresif. Chaplin mengatakan bahwa agresif adalah satu serangan atau serbuan tindakan permusuhan yang ditujukan pada seseorang atau benda ${ }^{15}$. Perilaku agresif merupakan sesuatu yang dipelajari dan bukannya perilaku yang dibawa individu sejak lahir. Perilaku agresif ini dipelajari dari lingkungan sosial seperti interaksi dengan keluarga, interaksi dengan rekan sebaya dan media massa melalui modelling.

Menurut Buss dan Perry, terdapat empat aspek perilaku agresif yang didasari dari tiga dimensi dasar yaitu motorik, afektif, dan kognitif $^{16}$. Empat aspek perilaku agresif yang dimaksud yaitu:

\section{Physical aggression}

Physical aggression yaitu tindakan agresi yang bertujuan untuk menyakiti, mengganggu, atau membahayakan orang lain melalui respon motorik dalam bentuk fisik, seperti memukul, menendang, dan lain-lain.

\section{Verbal aggression}

Verbal aggression yaitu tindakan agresi yang bertujuan untuk menyakiti, mengganggu, atau membahayakan orang lain dalam bentuk

\footnotetext{
${ }^{13}$ Sarwono, S. W, Psikologi Sosial (Jakarta: Balai Pustaka, 2002), h. 297.

${ }^{14}$ Dayakisni, T. H \& Hudaniah, Psikologi Sosial (Malang:UMM Press, 2006), 231.

${ }^{15}$ Chaplin, J. P, Kamus Lengkap Psikologi (Jakarta: PT Raja Grafindo Persada, 2004), h. 15

${ }^{16}$ Bush, A.H., \& Perry, M, "The Aggression Questionnaire", Journal of Personality and Social Psychology 63, 1992, h. 452. Baca juga Berkowitz, L., \& Green, R. G., "Stimulus Qualities of The Target of Aggression: A Futher Study", Journal of Personality and Social Psychology, Vol. 5, 1967).
}

penolakan dan ancaman melalui respon vokal dalam bentuk verbal.

3. Anger

Anger merupakan emosi negatif yang disebabkan oleh harapan yang tidak terpenuhi dan bentuk ekspresinya dapat menyakiti orang lain serta dirinya sendiri. Beberapa bentuk anger adalah perasaan marah, kesal, sebal, dan bagaimana mengontrol hal tersebut. Termasuk didalamnya adalah irritability, yaitu mengenai temperamental, kecenderungan untuk cepat marah, dan kesulitan mengendalikan amarah.

\section{Hostility}

Hostility yaitu tindakan yang mengekspresikan kebencian, permusuhan, antagonisme, ataupun kemarahan yang sangat kepada pihak lain. Hostility adalah suatu bentuk agresi yang tergolong agresi covert (tidak kelihatan). Hostility mewakili komponen kognitif yang terdiri dari kebencian seperti cemburu dan iri terhadap orang lain, dan kecurigaan seperti adanya ketidakpercayaan, kekhawatiran.

Dampak utama dari perilaku agresif ini adalah anak tidak mampu berteman dengan anak lain atau bermain dengan teman-temannya. Keadaan ini menciptakan lingkaran setan, semakin anak tidak diterima oleh teman-temannya, maka makin menjadilah perilaku agresif yang ditampilkannya. Remaja yang agresif memiliki toleransi yang rendah terhadap frustasi dan kurang mampu menunda kesenangan, cenderung bereaksi dengan cepat terhadap dorongan agresinya, kurang dapat melakukan refleksi diri, dan kurang dapat bertanggung jawab atas akibat perbuatannya.

Cornell, Peterson, \& Richards menyatakan bahwa amarah merupakan faktor predisposisi dari perilaku agresif dan amarah itu paralel dengan dorongan agresi sehingga intervensi terhadap amarah perlu dilakukan sebagai sarana 
mengurangi perilaku agresif seseorang ${ }^{17}$. Agresi yang dilakukan berturut-turut dalam jangka lama, apalagi jika terjadi pada anak-anak atau sejak masa kanak-kanak, dapat mempunyai dampak pada perkembangan kepribadian. Subjek dengan tingkat amarah yang tinggi cenderung memiliki strategi koping yang destruktif; mengekspresikan amarah dengan cara menyerang orang dan benda secara fisik dan verbal; lebih banyak menantang dan berperilaku negatif; serta lebih sering mengalami konflik dengan orang lain.

Perilaku agresif siswa di sekolah formal maupun non formal sudah menjadi masalah yang universal dan akhir-akhir ini cenderung semakin meningkat. Perilaku agresif banyak terjadi pada anak usia sekolah terutama pada masa perkembangan remaja. ${ }^{18}$ Salah satu lembaga pendidikan nonformal yang ada di kota Bukittinggi ini adalah Pusat Kegiatan Belajar Masyarakat (PKBM) Kasih Bundo. Pada lembaga pendidikan ini diselenggarakan pendidikan paket A, paket B dan paket C. Lembaga pendidikan ini menyelenggarakan pendidikan kepada 345 orang siswanya yang berada pada rentangan usia $7 \mathrm{~s} / \mathrm{d}$ 21 tahun. Pada umumnya siswa yang belajar di PKBM Kasih Bundo dapat dikategorikan dalam masa perkembangan remaja awal sampai remaja akhir.

Berdasarkan hasil wawancara dengan ketua PKBM Kasih Bundo pada bulan Maret 2016, diperoleh informasi bahwa banyak di antara siswa yang telah berusia 15 tahun ke atas melakukan tindakan kekerasan kepada siswa yang usianya lebih kecil dari mereka. Kekerasan yang mereka lakukan berupa kekerasan verbal seperti hinaan, cemoohan, cacian, umpatan, tudingan dan kata-

${ }^{17}$ Cornell, D.G., Peterson, C.S., \& Richards, H, "Anger as a Predictor of Aggression among Incarcerated Adolescent", Journal of Consulting and Clinical Psychology, 62, 1999, h. 108-115.

${ }^{18}$ Zamzami, A., "Agresivitas Siswa SMK DKI Jakarta", Jurnal Pendidikan dan Kebudayaan, Vol. 1, 2010, h. 32. Lihat juga, Wilson Sandra Jo and Mark W. Lipsey., "The Effects of School-Based Intervention Programs on Aggressive Behavior: A Meta-Analysis", Journal of Consulting and Clinical Psychology, Vol. 71, No. 1, 2003, h. 21. kata yang tidak senonoh. Selain itu, mereka juga melakukan kekerasan fisik berupa menendang, menampar, memukul dan berusaha menyakiti fisik anak yang lemah.

Bahkan ada di antara mereka yang memanfaatkan teman mereka untuk mendapatkan untung bagi mereka. Mereka yang senior menyuruh temannya yang junior untuk mendapatkan uang dengan berbagai cara untuk diserahkan pada mereka. Jika teman mereka yang junior tidak bisa memenuhinya, maka yang senior akan memberikan hukuman yang berat. Hal ini yang akan semakin memperburuk moral bangsa, jika dibiarkan terus berkembang.

Jika dilihat dari segi pemenuhan kebutuhan fisik remaja dari orang tua, pada umumnya kebutuhan fisik mereka terpenuhi dengan baik. Dapat dilihat dari keadaan fisik mereka yang sehat, pakaian mereka yang memadai bahkan dapat dikatakan bagus, mereka diberi uang yang cukup untuk keperluan sekolah, bahkan mereka difasilitasi dengan kendaraan ke sekolah. Dari segi penampilan fisik mereka, dapat dinilai bahwa orang tua mereka mencoba untuk memenuhi kebutuhan fisik mereka dengan baik. Namun, untuk pemenuhan kebutuhan psikis yang diberikan orang tua memang belum sebagus pemenuhan kebutuhan fisik mereka. Banyak dari mereka kurang mendapatkan perhatian dari orangtua mereka. Mereka tidak memiliki hubungan yang akrab dengan orangtua, karena kesibukan orangtua di luar rumah. Hal ini membuat mereka mencari kesenangan lain di luar rumah.

Agar penelitian ini lebih terarah sesuai dengan tujuan yang diinginkan, maka peneliti mencoba untuk membuat skema atau bagan yang dapat menuntun pemikiran peneliti dalam pengembangan kegiatan mengungkapkan penelitian ini. Adapun skemanya adalah sebagai berikut:

\section{Gambar 1. Skema Perilaku Agresif}

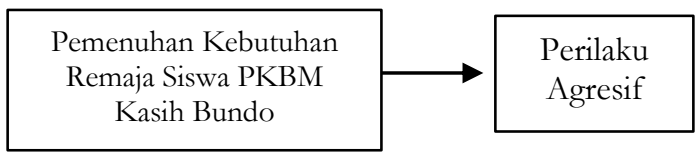


Berdasarkan skema di atas, penelitian ini dilaksanakan pada siswa PKBM Kasih Bundo Kota Bukittinggi. Penelitian ini ingin mengungkapkan tentang pengaruh pemenuhan kebutuhan remaja siswa PKBM Kasih Bundo terhadap perilaku agresif yang dilakukannya. Hasil instrumen penelitian ini akan diolah dengan menggunakan rumus stastistik, untuk melihat pengaruh pemenuhan kebutuhan remaja terhadap perilaku agresif yang dilakukannya. Hasil pengolahan ini akan menguji hipotesis penelitian yang diajukan.

Hipotesis yang diajukan dalam penelitian ini berdasarkan teori yang telah dikemukakan di atas adalah :

Hipotesis Alternatif $(\mathrm{Ha})$ : Terdapat yang signifikan antara pemenuhan kebutuhan remaja terhadap perilaku agresif siswa di PKBM Kasih Bundo Kota Bukittinggi.

Hipotesis Nihil (Ho): Tidak terdapat pengaruh yang signifikan antara pemenuhan kebutuhan remaja terhadap perilaku agresif siswa di PKBM Kasih Bundo Kota Bukittinggi.

\section{Metodologi}

Penelitian ini merupakan penelitian kuantitatif dengan rancangan penelitian korelasional. A. Muri Yusuf menjelaskan bahwa penelitian korelasional merupakan suatu tipe penelitian yang melihat hubungan antara satu atau beberapa ubahan dengan satu atau beberapa ubahan yang lain. ${ }^{19}$ Dengan teknik korelasi seorang peneliti dapat mengetahui hubungan variasi dalam sebuah variabel dengan variasi yang lain.

Populasi dalam penelitian ini adalah seluruh siswa PKBM Kasih Bundo Kota Bukittinggi yang berjumlah 345 orang. Sementara sampel dalam penelitian ini diambil dengan menggunakan teknik purposive sampling. Sesuai dengan tujuan penelitian bahwa data yang diambil dalam penelitian ini

${ }^{19}$ A.Muri Yusuf, Metodologi Penelitian (Padang: UNP Press, 2005), h. 83. adalah data tentang anak berusia remaja madya. Oleh karena itulah penelitian ini menggunakan teknik purposive sampling. Sampel dalam penelitian ini hanya dibatasi pada anak yang berusia remaja madya dengan rentangan usia 13-16 tahun. Dari populasi, hanya terdapat 66 orang anak yang berada pada rentangan usia tersebut.

Alat ungkap yang digunakan untuk mendapatkan data tentang pemenuhan kebutuhan remaja dan perilaku agresif adalah angket. Angket yang penulis gunakan adalah alat ungkap yang penulis susun sendiri dengan menggunakan skala likert. Teknik analisis data yang digunakan dalam penelitian ini adalah rumus product moment yang dikemukakan oleh Pearson. Teknik analisa data menggunakan statistik sederhana dan dalam pengkorelasian variabel penelitian menggunakan Statiscal Product and Service Solution (SPSS) versi 21.0. Untuk melihat besarnya pengaruh antar variabel dalam penelitian ini maka dihitung koefisien determinasinya.

\section{Kebutuhan Remaja Siswa PKBM Kasih Bundo}

Sesuai dengan variabel penelitian, dalam deskripsi data ini akan dikemukakan hasil penelitian berkaitan dengan kebutuhan remaja dan perilaku agresif siswa PKBM Kasih Bundo Kota Bukittinggi. Berikut ini akan dipaparkan hasil pengolahan dari angket tersebut.

Untuk dapat melihat gambaran kebutuhan remaja siswa PKBM Kasih Bundo kota Bukittinggi secara keseluruhan dapat dilihat pada tabel berikut:

Tabel 1. Kebutuhan Remaja Siswa PKBM Kasih Bundo N = 66

\begin{tabular}{|c|c|c|c|c|c|c|c|}
\hline \multirow{3}{*}{ No } & \multirow{3}{*}{$\begin{array}{c}\text { Aspek } \\
\text { Kebutuhan } \\
\text { Remaja }\end{array}$} & \multicolumn{6}{|c|}{ Deskriptif Statistik } \\
\hline & & \multicolumn{2}{|c|}{ Mean } & \multirow{2}{*}{$\mathrm{SD}$} & \multirow{2}{*}{ Range } & \multicolumn{2}{|c|}{ Skor } \\
\hline & & Skor & $\%$ & & & Min & Max \\
\hline 1 & $\begin{array}{c}\text { Kebutuhan } \\
\text { Fisik } \\
\text { Remaja }\end{array}$ & 3,3 & $\begin{array}{r}66 \\
, 7\end{array}$ & $\begin{array}{l}1 \\
2\end{array}$ & 5 & 0 & 5 \\
\hline 2 & $\begin{array}{c}\text { Kebutuhan } \\
\text { Psikis } \\
\text { Remaja }\end{array}$ & 3,4 & 69 & $\begin{array}{l}1 \\
3\end{array}$ & 5 & 0 & 5 \\
\hline
\end{tabular}




$\begin{array}{lrrrrrr}\text { Rata-rata } & 3,35 & \begin{array}{r}67 \\ 8\end{array} & 1, & 5 & 0 & 5\end{array}$

Pada tabel 1 di atas, diperoleh gambaran bahwa kebutuhan remaja siswa PKBM Kasih Bundo secara umum dikategorikan tinggi. Hal ini dapat dilihat pada persentase rata-rata skor yaitu sebesar 67,8\% dengan SD 1,25. Dari besaran angka perolehan hasil penelitian diketahui bahwa pemenuhan kebutuhan remaja di PKBM Kasih Bundo terpenuhi dengan baik.

\section{Perilaku Agresif Siswa PKBM Kasih Bundo}

Untuk dapat melihat gambaran perilaku agresif siswa PKBM Kasih Bundo kota Bukittinggi secara keseluruhan dapat dilihat pada tabel berikut:

\section{Tabel 2. Perilaku Agresif Siswa PKBM Kasih Bundo Kota Bukittinggi $\mathrm{N}=66$}

\begin{tabular}{|c|c|c|c|c|c|c|}
\hline \multirow{3}{*}{ No } & \multirow{3}{*}{$\begin{array}{c}\text { Aspek } \\
\text { Perilaku } \\
\text { Agresif }\end{array}$} & \multicolumn{5}{|c|}{ Deskriptif Statistik } \\
\hline & & \multicolumn{2}{|c|}{ Mean } & \multirow{2}{*}{ Range } & \multicolumn{2}{|c|}{ Skor } \\
\hline & & $\overline{\text { Skor }}$ & $\%$ SD & & Min & Max \\
\hline 1 & $\begin{array}{c}\text { Physical } \\
\text { Aggression }\end{array}$ & 3,9 & $74,51,3$ & 4,3 & 0,6 & 5 \\
\hline 2 & $\begin{array}{c}\text { Verbal } \\
\text { Aggression }\end{array}$ & 4 & $79,51,2$ & 3,1 & 0,15 & \\
\hline 3 & Anger & 3,5 & $70,51,4$ & 5 & 0 & 5 \\
\hline 4 & Hostility & 3,7 & $73,3 \quad 1,3$ & 4,2 & 0,7 & 5 \\
\hline & ata-rata & 3,7 & $74,4 \quad 1,3$ & 4,1 & 0,3 & 5 \\
\hline
\end{tabular}

Pada tabel 2 di atas, diperoleh gambaran bahwa perilaku agresif siswa PKBM Kasih Bundo kota Bukittinggi dikategorikan tinggi. Hal ini dapat dilihat pada persentase rata-rata skor yaitu sebesar 74,4\% dengan SD 1,3. Dari besaran angka perolehan hasil penelitian diketahui bahwa perilaku agresif remaja di PKBM Kasih Bundo terjadi dengan intensitas yang tinggi. Berarti dalam rutinitas sekolah yang mereka jalani terdapat banyak praktik perilaku agresif yang dilakukan oleh para siswa PKBM Kasih Bundo.

\section{Hipotesis Penelitian}

Hipotesis yang diajukan dalam penelitian ialah terdapat pengaruh yang signifikan antara pemenuhan kebutuhan remaja terhadap perilaku agresif. Untuk uji hipotesis dipilih analisis statistik dengan teknik Pearson Product Moment dengan bantuan program SPSS versi 21.0.

Tabel 3. Hasil Analisis Pemenuhan Kebutuhan Remaja dengan Perilaku Agresif

\begin{tabular}{lccc}
\hline \multicolumn{4}{c}{ Correlations } \\
\hline \multicolumn{3}{c}{$\begin{array}{c}\text { Kebut } \\
\text { uhan }\end{array}$} & Agresif \\
\hline Kebutuhan & $\begin{array}{c}\text { Pearson } \\
\text { Correlation }\end{array}$ & 1 & $.252^{*}$ \\
\cline { 2 - 4 } & Sig. (2-tailed) & .041 \\
\cline { 2 - 4 } Agresif & $\mathrm{N}$ & 66 & 66 \\
\hline & Pearson & $.252^{*}$ & 1 \\
\cline { 2 - 4 } & Correlation \\
\cline { 2 - 4 } & Sig. (2-tailed) & .041 & \\
\cline { 2 - 4 } & $\mathrm{N}$ & 66 & 66 \\
\hline *. Correlation is significant at the 0.05 level (2-tailed). \\
\hline
\end{tabular}

Berdasarkan tabel 3 di atas, dapat dilihat bahwa probabilitas (Sig. 2-tailed) hubungan pemenuhan kebutuhan remaja dengan perilaku agresif siswa PKBM Kasih Bundo sebesar 0,041 atau probabilitas di bawah alpha 0,05 $(0,041<$ $0,05)$ dan $r_{\text {hitung }}>r_{\text {tabel, }}$ dimana $r_{\text {hitung }}$ sebesar 0,252 sedangkan $r_{\text {tabel }}$ sebesar 0.242 dengan df 64. Hal ini berarti bahwa jika $p$ lebih kecil dari $\alpha$ dan $r_{\text {hitung }}>$ $\mathrm{r}_{\text {tabel, }}$ maka $\mathrm{H}_{0}$ ditolak dan $\mathrm{H}_{1}$ diterima, berarti terdapat hubungan yang signifikan antara pemenuhan kebutuhan remaja dengan perilaku agresif siswa PKBM Kasih Bundo kota Bukittinggi. Dengan koefisien determinasi 6,35\%. Dapat diartikan bahwa pemenuhan kebutuhan remaja berhubungan dengan perilaku agresif yang dilakukannya dalam kehidupan. Dimana pemenuhan kebutuhan remaja mempengaruhi 6,35\% perilaku agresif pada diri remaja. Sedangkan 93,65\% lainnya dipengaruhi oleh berbagai faktor yang lainnya.

\section{Pembahasan}

Berdasarkan deskripsi data, terungkap bahwa pemenuhan kebutuhan remaja siswa PKBM Kasih Bundo secara umum dikategorikan tinggi. Hal ini dapat dilihat pada persentase ratarata skor yaitu sebesar 67,8\% dengan SD 1,25. 
Dapat dikatakan, bahwa siswa PKBM Kasih Bundo telah terpenuhi kebutuhan remajanya baik secara fisik maupun secara psikis. Pemenuhan kebutuhan secara fisik yaitu berupa makan, minum, udara segar, temperatur, beraktivitas maupun beristirahat telah terpenuhi secara baik. Begitu juga halnya dengan kebutuhan psikis yaitu berupa mendapatkan status, mandiri, berprestasi, diakrabi dan filsafat hidup telah terpenuhi dengan baik.

Hasil penelitian ini didukung oleh pendapat F. J. Monk yang menyatakan bahwa kebutuhan remaja adalah segala sesuatu yang muncul secara naluriah dan sangat diperlukan oleh remaja untuk dapat menjalankan masa perkembangan remajanya dan memenuhi tugas perkembangannya. ${ }^{20}$ Kebutuhan remaja dapat dipuaskan dengan berbagai cara misalnya kebutuhan sosial dapat dipuaskan melalui penerimaan sosial dan dapat juga dengan menghadapkan mereka pada berbagai tantangan sosial atau kesulitan sosial.

Deskripsi data tentang perilaku agresif siswa PKBM Kasih Bundo Kota Bukittinggi dikategorikan tinggi. Hal ini dapat dilihat pada persentase rata-rata skor yaitu sebesar $74,4 \%$ dengan SD 1,3. Dapat dikatakan bahwa pada umumnya siswa PKBM Kasih Bundo kota Bukittinggi melakukan perilaku agresif terhadap orang lain dengan tujuan untuk menimbulkan kesakitan bagi si korban. Moore dan Fine dalam Koeswara mendefinisikan agresi sebagai tingkah laku kekerasan secara fisik ataupun secara verbal terhadap individu lain ataupun terhadap objekobjek $^{21}$. Perilaku agresif tidak hanya dilakukan terhadap makhluk hidup, tetapi juga terhadap benda-benda atau objek lainnya seperti benda mati.

${ }^{20}$ F. J. Monks; A.M.P. Knoers; Siti Rahayu Haditono, Psikologi Perkembangan (Yogyakarta: UGM PRESS, 2006), h. 275.

${ }^{21}$ Koeswara, E, Agresi Manusia (Bandung: PT. Eresco, 1988), h. 5
Hasil analisis data dan pengujian hipotesis pada penelitian ini dapat diterima. Berdasarkan hasil perhitungan pearson product moment untuk data penelitian ini diperoleh sebesar 0,041 atau probabilitas di bawah alpha 0,05 $(0,041<0,05)$ dan $r_{\text {hitung }}>r_{\text {tabel, }}$ dimana $r_{\text {hitung }}$ sebesar 0,252 sedangkan $r_{\text {tabel }}$ sebesar 0.242 dengan df 64 . Hal ini berarti bahwa jika $p$ lebih kecil dari $\alpha$ dan $r_{\text {hitung }}>$ $\mathrm{r}_{\text {tabel }}$, maka $\mathrm{H}_{0}$ ditolak dan $\mathrm{H}_{1}$ diterima, berarti terdapat hubungan yang signifikan antara pemenuhan kebutuhan remaja dengan perilaku agresif siswa PKBM Kasih Bundo kota Bukittinggi. Dengan koefisien determinasi 6,35\%. Dapat diartikan bahwa pemenuhan kebutuhan remaja berhubungan dengan perilaku agresif yang dilakukannya dalam kehidupan. Dimana pemenuhan kebutuhan remaja mempengaruhi $6,35 \%$ perilaku agresif pada diri remaja. Sedangkan 93,65\% lainnya dipengaruhi oleh berbagai faktor yang lainnya.

Buss dan Perry menyatakan bahwa secara umum perilaku agresif dipengaruhi oleh dua faktor utama, yakni faktor personal dan faktor situasional $^{22}$. Faktor personal meliputi karakter bawaan individu yang menentukan reaksi individu tersebut ketika menghadapi situasi tertentu. Sementara itu, faktor situasional mencakup fiturfitur atau hal-hal yang terjadi di lingkungan yang juga mempengaruhi reaksi individu terhadap suatu peristiwa. Faktor personal dan faktor situasional dapat diuraikan sebagai berikut:

Pertama, faktor personal terdiri dari a) Sifat. Sifat-sifat tertentu dapat menyebabkan seseorang lebih agresif dari orang lain. Misalnya, individu yang memiliki sifat pemcemburu akan lebih agresif; b) Jenis kelamin Laki-laki dan perempuan memiliki kecenderungan perilaku agresif yang berbeda. Laki-laki terbukti lebih banyak terlibat tindakan agresif dibandingkan perempuan, dan pilihan agresif antara laki-laki dan perempuan terbukti berbeda. Perempuan lebih

Bush, A.H., \& Perry, M, The Aggression Questionnaire,
... h. 457 . 
memilih agresif tidak langsung dan laki-laki lebih banyak terlibat pada perilaku agresif langsung.

Kedua, faktor keyakinan. Individu yang memiliki keyakinan bahwa dirinya mampu melakukan tindakan agresif lebih mungkin memilih melakukan tindakan agresif ketimbang individu yang tidak yakin bahwa dirinya dapat melakukan tindakan agresif.

Ketiga, faktor sikap. Sikap adalah evaluasi umum seseorang terhadap diri mereka sendiri, orang lain, objek-objek ataupun isu-isu tertentu. Sikap positif terhadap perilaku agresif terbukti mempersiapkan individu untuk melakukan tindakan agresif. Sebaliknya, sikap negatif terhadap perilaku agresif terbukti mencegah seseorang untuk melakukan tindakan agresif

Keempat, faktor nilai. Nilai adalah keyakinan mengenai apa yang harus dan sebaiknya dilakukan. Nilai yang dianut seseorang mempengaruhi keputusannya untuk melakukan perilaku agresif. Contohnya, orang yang menganut nilai bahwa kekerasan itu diperbolehkan untuk mengatasi konflik interpesonal lebih berperilaku agresif untuk menyelesaikan konflik yang dihadapinya.

Kelima, tujuan jangka panjang. Tujuan jangka panjang juga mempengaruhi kesiapan individu untuk terlibat dalam perilaku agresif. Misalnya, tujuan beberapa anggota geng adalah dihormati dan dihargai. Tujuan inilah mewarnai persepsi, nilai-nilai, dan keyakinan anggota geng mengenai pantas atau tidaknya melakukan tindakan tertentu, dan akhirnya mempengaruhi keputusan anggota geng untuk terlibat dalam perilaku agresif.

Di samping itu terdapat faktor situasional yang terdiri dari; pertama, petunjuk untuk melakukan tindakan agresif (aggressive cues). Aggressive Cues adalah objek yang menimbulkan konsep-konsep yang berhubungan dengan agresi dalam memori. Kedua, provokasi. Provokasi mencakup hinaan, ejekan, sindiran kasar, serta bentuk agresif verbal lainnya, agresi fisik, dan gangguan-gangguan yang menghambat pencapaian suatu tujuan atau sejenisnya.
Ketiga, frustrasi. Frustrasi terjadi ketika individu menemui hambatan untuk mencapai tujuan. Seseorang yang mengalami frustrasi terbukti lebih agresif terhadap agen yang menyebabkan terhalang pencapaian tujuan, ataupun pada pihak-pihak yang sebenarnya tidak bertanggungjawab atas gagalnya pencapaian tujuan. Selain itu, individu yang mengalami frustrasi juga terbukti melampiaskan rasa frustasinya dengan menyerang benda-benda di sekitarnya.

Keempat, rasa sakit dan ketidaknyamanan. Kondisi-kondisi fisik lingkungan yang menyebakan ketidaknyamanan dapat meningkatkan perilaku agresif. Lingkungan yang bising, terlalu panas, ataupun berbau tidak sedap terbukti meningkatkan perilaku agresif.

Kelima, obat-obatan. Penggunaan obatobatan atau zat-zat tertentu seperti kafein atau alkohol terbukti meningkatkan perilaku agresif secara tidak langsung. Individu yang berada dibawah pengaruh obat-obatan atau zat-zat tertentu akan mudah terprovokasi, mudah merasa frustasi, dan mudah menangkap petunjuk untuk melakukan kekerasan dibandingkan individu yang tidak menggunakan obat-obatan tertentu.

Kelima, insentif. Pada dasarnya individu memiliki kecenderungan untuk selalu menginginkan yang lebih banyak sehingga ada banyak objek yang dapat digunakan sebagai insentif yang diberikan pada seseorang untuk melakukan tindakan agresif. Perilaku agresif dapat dimediasi dengan memberikan imbalan berupa hal yang dianggap berharga oleh pelaku.

Hasil penelitian ini didukung oleh pendapat yang dikemukakan Hardy and Gull dalam Elida Prayitno, yang berpendapat bahwa apabila kebutuhan remaja itu terintangi atau tidak terpuaskan akan timbul perasaan kecewa atau frutrasi $^{23}$. Apabila kebutuhan sosial-psikologis tidak terpenuhi maka akan mengakibatkan timbulnya rasa tidak puas, menjadi frustasi dan

${ }^{23}$ Elida Prayitno, Psikologi Perkembangan Remaja, h. 32. 
terhambatnya pertumbuhan serta perkembangan sikap positif terhadap lingkungan dan dirinya. Sebagai contoh masa remaja disebut pula sebagai masa social hunger (kehausan sosial), yang ditandai dengan adanya keinginan untuk bergaul dan diterima di lingkungan kelompok sebayanya (per kelompok). Penolakan dari kelompok dapat menimbulkan frustrasi dan menjadikan dia sebagai isolated dan merasa rendah diri.

Selanjutnya Blair \& Stewart dalam Elida Prayitno mengemukakan pendapat bahwa remaja yang kebutuhan-kebutuhannya tidak terpenuhi dapat melakukan tingkah laku mekanisme pertahanan diri seperti tingkah laku agresif, kompensasi, identifikasi, rasionalissai, proyeksi, pembentukan reaksi, egosentrism, menarik diri dan gangguan pertumbuhan fisik ${ }^{24}$. Reaksi-reaksi dan ekspresi emosional yang masih labil dan belum terkendali pada masa remaja dapat berdampak pada kehidupan pribadi maupun sosialnya. ${ }^{25}$

\section{Kesimpulan}

Berdasarkan hasil penelitian yang telah dijelaskan terdahulu, dapat disimpulkan bahwa hasil analisis data dan pengujian hipotesis pada penelitian ini dapat diterima. Dimana $\mathbf{r}_{\text {hitung }}$ sebesar 0,252 sedangkan $r_{\text {tabel }}$ sebesar 0.242 dengan df 64 . Hal ini berarti bahwa jika $p$ lebih kecil dari $\alpha$ dan $\mathrm{r}_{\text {hitung }}>\mathrm{r}_{\text {tabel, }}$, maka $\mathrm{H}_{0}$ ditolak dan $\mathrm{H}_{1}$ diterima, berarti terdapat hubungan yang signifikan antara pemenuhan kebutuhan remaja dengan perilaku agresif siswa PKBM Kasih Bundo kota Bukittinggi. Dengan koefisien determinasi 6,35\%.

Berdasarkan kesimpulan di atas, peneliti memberikan beberapa saran kepada siswa PKBM Kasih Bundo kota Bukittinggi, agar dapat mengendalikan dirinya dengan baik supaya tidak terjadi perilaku agresif yang merugikan diri sendiri dan orang lain. kepada orang tua dan tutor di PKBM Kasih Bundo untuk dapat meningkatkan

${ }^{24}$ Elida Prayitno, Psikologi Perkembangan Remaja, h. 33. ${ }^{25}$ Elida Prayitno, Psikologi Perkembangan Remaja, h. 32. pemenuhan kebutuhan remaja baik fisik maupun psikis bagi siswa PKBM Kasih Bundo agar mereka dapat terhindar dari perilaku agresif. Kepada orang tua dan tutor di PKBM Kasih Bundo untuk dapat memberikan teladan dan peringatan bagi siswa PKBM Kasih Bundo yang melakukan perilaku agresif agar dapat berkembang menjadi generasi muda yang konstruktif. Kepada pihak yayasan PKBM Kasih Bundo untuk dapat menyediakan tenaga ahli seperti konselor atau psikolog untuk membantu mencegah dan menanggulangi perilaku agresif siswa.

\section{Daftar Pustaka}

\section{Buku Teks}

Chaplin, J. P., Kamus Lengkap Psikologi (Jakarta: PT Raja Grafindo Persada, 2004).

Dayakisni, T. H \& Hudaniah, Psikologi Sosial (Malang:UMM Press, 2006).

Elida Prayitno dan Erlamsyah, Psikologi Perkembangan Remaja (Padang: UNP Press, 2002).

Koeswara, E., Agresi Manusia (Bandung: PT. Eresco, 1988).

Mappiare, Andi, Psikologi Remaja (Surabaya: Usaha Nasional, 1982).

Monks, F. J. dan A.M.P. Knoers; Siti Rahayu Haditono, Psikologi Perkembangan (Yogyakarta: UGM Press, 2006).

Sarwono, S. W., Psikologi Sosial (Jakarta: Balai Pustaka, 2002).

Yusuf, A. Muri, Metodologi Penelitian (Padang: UNP Press, 2005).

\section{Jurnal}

Berkowitz, L., \& Green, R. G., "Stimulus Qualities of The Target of Aggression: A Futher Study", Journal of Personality and Social Psychology, Vol. 5, 1967.

Bush, A.H., \& Perry, M., "The Aggression Questionnaire" Journal of Personality and Social Psychology 63. 1992 
Cornell, D.G., Peterson, C.S., \& Richards, H. "Anger as a Predictor of Aggression Among Incarcerated Adolescent", Journal of Consulting and Clinical Psychology, Vol. 62, 1999.

Wilson Sandra Jo and Mark W. Lipsey., "The Effects of School-Based Intervention Programs on Aggressive Behavior: A MetaAnalysis" Journal of Consulting and Clinical Psychology, Vol. 71, No. 1, 2003.

Zamzami, A., "Agresivitas Siswa SMK DKI Jakarta", Jurnal Pendidikan dan Kebudayaan, Vol. 1, 2010. 